\title{
ANALISIS DESAIN PICKUP PIEZOELEKTRIK ELEMEN DARI MODEL HYBRID SOLAR CELL-PIEZOELECTRIC UNTUK DAYA RENDAH
}

\author{
Ery Diniardi ${ }^{1}$, Syawaluddin ${ }^{1}$, Anwar Ilmar Ramadhan ${ }^{1, *}$, Waldi Isnaini ${ }^{1}$, \\ Erwin Dermawan ${ }^{2}$, Deni Almanda ${ }^{2}$
}

\author{
${ }^{1}$ Jurusan Teknik Mesin, Fakultas Teknik, Universitas Muhammadiyah Jakarta, Indonesia \\ ${ }^{2}$ Jurusan Teknik Elektro, Fakultas Teknik, Universitas Muhammadiyah Jakarta, Indonesia \\ *Email: anwar.ilmar@umj.ac.id
}

\begin{abstract}
ABSTRAK
Indonesia merupakan negera yang memiliki sumber energi baru dan terbarukan yang belum dikembangkan secara optimal dan besar-besaran digali dan digunakan, terutama energy sel surya dan energi air hujan. Kelebihan dari iklim tropis, yaitu hujan dan panas, sudah seharusnya dikembangkan secara masif dan secara diversifikasi energy. Bukan hanya energy fosil yang digunakan, tetapi energy yang ada disekitar kita. Salah satunya energy air hujan dengan menggunakan Piezolektrik. Bahan piezoelektrik yang mampu mengubah energi mekanik menjadi energi listrik menjadi sumber utama pembahasan dalam penelitian ini. Banyaknya energi yang dihasilkan dari benturan air hujan dapat dihitung menggunakan model mekanik-elektrik. Besarnya energi yang bisa dihasilkan bergantung secara langsung kepada ukuran membran piezoelektrik, ukuran titik air hujan dan frekuensinya. Dan juga sel surya yang digunakan sebagai penghasil listrik. Apabila kedua energy ini digabungkan seperti apakah hasilnya. Dalam penelitian ini akan dikaji mengenai analisis desain pickup Piezoelektrik dari model hybrid pembangkit listrik ini.
\end{abstract}

Kata kunci: sel surya, piezoelektrik, energi, hybrid, model

\begin{abstract}
Indonesia is a country that has the new and renewable energy sources are not yet developed and massive excavated and used, especially energy solar cells and energy rainwater. The advantages of the tropical climate, the rain and heat, should be developed on a massive scale and the diversification of energy. Not only fossil energy is used, but the energy that is around us. One of this rain water energy by using Piezoelectric. The piezoelectric material capable of converting mechanical energy into electrical energy becomes a major source of discussion in this study. The amount of energy generated from impact of rain water can be calculated using mechanical-electric models. The amount of energy that can be produced depends directly on the size of the piezoelectric membrane, the size of raindrops and frequency. As well as solar cells used as electricity. When the two are combined energy such as whether the result. In this research will be assessed on the analysis of design of Piezoelectric from model of hybrid solar cell - Piezoelectric.
\end{abstract}

Keywords: solar cells, piezoelectric, energy, hybrid, model 


\section{PENDAHULUAN}

Dalam proses mengubah suatu energi menjadi bentuk energi lain diperlukan sebuah alat yang disebut dengan Tranduser. Dalam pengertian yang lebih luas, tranduser kadang-kadang juga didefinisikan sebagai sebagai suatu peralatan yang mengubah gaya atau perpindahan mekanis menjadi sinyal listrik (Almanda, 2015, Paulus, 2011, Febrawi, 2013). Tranduser Piezoelektrik merupakan salah satu jenis tranduser aktif dengan prinsip kerja pembangkitan listrik dari bahan kristal piezo akibat gaya dari luar [Sharma, 2006]. Tranduser jenis ini dapat menerima Inputan berupa suara, getaran maupun percepatan dalam cara kerjanya (Hananto, 2013).

Oleh karena itu diperlukan energi-energi alternatif selain energi fosil yang dapat digunakan sebagai pengganti energi fosil. Energi yang dikembangkan tersebut haruslah energi baru dan terbarukan. Energi baru dan terbarukan adalah energi yang belum lazim digunakan dimasyarakat serta proses daur ulang atau sumberdaynya mudah dan berlimpah. Energi baru dan terbarukan yang telah dikembangkan didunia umumnya adalah energi yang memiliki karakteristik masingmasing pada setiap wilayah. Seperti Kincir angin pada negara belanda dimana pada wilayah belanda memiliki laju angin yang besar sepanjang tahun (Krisdianto, 2011). Indonesia yang memiliki dua musim yaitu musim panas dan musim hujan, memiliki potensi energi-energi terbarukan dari dua musim tersebut. Yaitu tenaga surya dan tenaga tumbukan dari hujan.

Piezoelektrik adalah sebuah material yang apabila diberi tekanan akan menghasilkan arus listrik Menurut penelitian sebelumnya pengembangan terhadap piezoelektrik sudah diterapkan di beberapa wilayah misalnya Yogyakarta berupa piezoelektrik sebagai sistem deteksi dini gempa, dan sebagai penghasil listrik yang dihasilkan dengan cara memberikan tekanan pada piezoelektrik (Rahayu, 2013). Pengembangan piezoelektrik sebagai penghasil listrik diterapkan dengan beberapa pengaplikasian misalnya diletakan di alas sepatu, bola, alas keset dan pada polisi tidur. Banyaknya pembuatan piezoelektrik dibeberapa pengaplikasian mendorong peneliti untuk membuat piezoelektrik dengan memanfaatkan energi alam, hal ini bertujuan untuk mengurangi penggunaan listrik dari pemerintah.

Indonesia merupakan negara tropis, sehingga membuat Indonesia memiliki dua musim yaitu musim hujan dan musim kemarau. Pemanfaatan alam sebagai energi listrik pada musim kemarau dimanfaatkan dengan cara memanfaatkan panas matahari sebagai energi yang disimpan pada siang hari dan dimanfaatkan atau digunakan sebagai listrik pada malam hari. Namun, pada musim hujan belum ada pemanfaatan energi yang dapat dimanfaatkan atau digunakan sebagai energi listrik. Sehingga dalam hal ini peneliti bermaksud memanfaatkan energi yang dihasilkan dari tekanan air hujan yang turun dari langit sebagai energi tekan pada piezoelektrik. Dengan bantuan tekanan air hujan pada piezoelektrik, maka piezoelektrik dapat menghasilkan energi listrik yang dapat digunakan untuk keperluan sehari-hari, seperti penerangan (Widodo, dkk, 2015).

Selain itu energi matahari dapat dimanfaatkan dengan bantuan peralatan lain, yaitu dengan merubah radiasi matahari kebentuk lain. Ada dua macam cara merubah radiasi matahari ke dalam energi lain, yaitu melalui solar cell dan collector. Tidak diragukan lagi bahwa energi surya adalah salah satu sumber energi yang ramah lingkungan dan sangat menjanjikan pada masa yang akan datang, karena tidak ada polusi yang dihasilkan selama proses konversi energi, dan juga sumber energinya banyak tersedia di alam. (Almanda, dkk, 2016)

Oleh karena itu penerapan teknologi Pembangkit Listrik Tenaga Surya (PLTS) untuk memanfaatkan potensi energi surya yang tersedia dilokasi-lokasi tersebut merupakan solusi yang tepat (Ramadhan, dkk, 2016).

PLTS atau lebih dikenal dengan sel surya (sel Photovoltaic) akan lebih diminati karena dapat digunakan untuk berbagai keperluan yang relevan dan di berbagai tempat seperti perkantoran, pabrik, perumahan, dan lainnya. Sehingga hal ini dipandang perlu untuk dikaji lebih lanjut. Agar diperoleh kajian yang komprehensif secara teknik. (Ubaidillah, dkk, 2012) 
Didalam penelitian ini tranduser piezoelektrik dengan luasan tertentu dijadikan sebagai media konversi energi yaitu gaya tekan air hujan yang jatuh menjadi energi listrik. Sehingga nantinya dapat diketahui seberapa besar energi listrik yang dihasilkan. Untuk mengetahui besaran nilai energi-nya maka dilakukan analisis desain Piezoelektrik pada elemen dari model Solar Cell-Piezoelectric, agar dapat diketahui pola sebaran dan susunan piezoelectric.

\section{METODE PENELITIAN}

Metodologi atau pendekatan yang akan dilakukan adalah pemodelan awal dari desain yang akan digunakan untuk membran pizoelektrik dan sel surya sebagai media penghasil energi listrik yang bersumber dari pengaruh gaya tekan atau tumbukan yang bersumber dari rintik air hujan dan juga sinar matahari berdasarkan wilayah di Indonesia. Langkah-langkah metodologinya, sebagai berikut:

1. Melakukan studi literatur dan melakukan analisis berdasarkan datadata awal dari penelitian mengenai pembuatan membran pizoelektrik dan juga mengenai perubahan energi listrik yang bersumber dari gaya tekan yang pernah dilakukan dan studi literatur mengenai sel surya yang akan digunakan.

2. Melakukan perhitungan dan analisis desain pick up Piezoelektrik elemen untuk model Hybrid Solar CellPizeoelectric.

Langkah penelitian dapat dilihat pada Gambar 1.

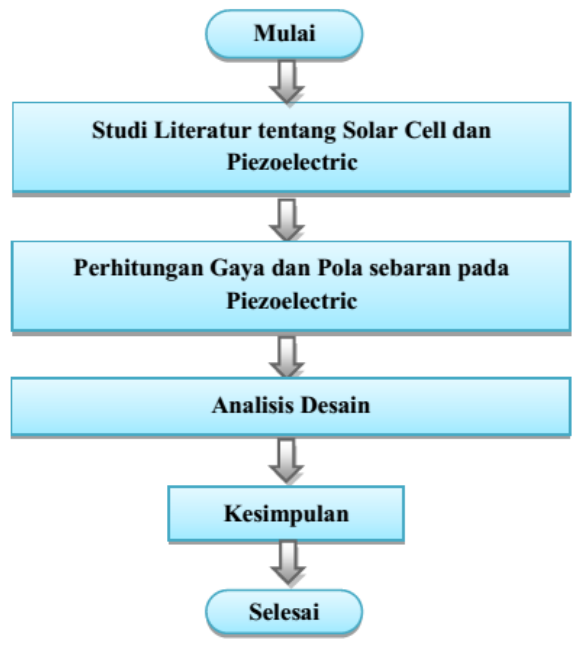

Gambar 1. Alur penelitian yang dilakukan
HASIL DAN PEMBAHASAN

Perhitungan Gaya pada Piezoelectric Elemen

Untuk analisa desain piezoelectric beberapa hal yang akan diperhatikan adalah perhitungan gaya, jarak antar piezo, dan tegangan yang didapatkan.

Berdasarkan hasil penelitian sebelumnya yang dilakukan oleh Almanda, dkk, 2016. Desain yang diujicobakan seperti pada Gambar 2 dan Gambar 3.

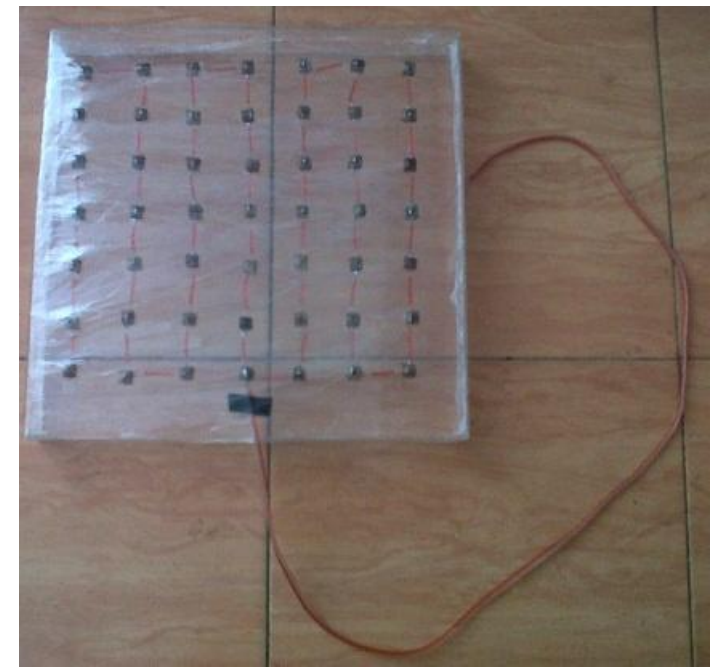

Gambar 2. Rangkaian Seri Piezoelektrik Setelah Dilapisi Plastik Mika Transparan (Almanda, dkk, 2016)

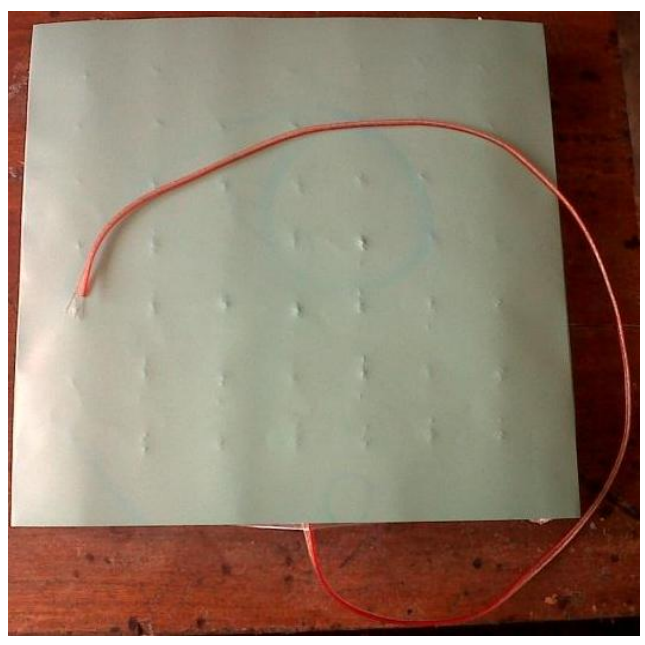

Gambar 3. Rangkaian Seri Piezoelektrik Setelah Dilapisi Plat Alumunium (Almanda, dkk, 2016) 
Berdasarkan desain Gambar 2 dan 3. Terdapat beberapa hal yang akan dilakukan analisis terhadap posisi Piezoelektrik, yaitu:

Jika dijabarkan sesuai gambar pada gaya yang terjadi pada sumbu X. Tergambarkan seperti Gambar 4.

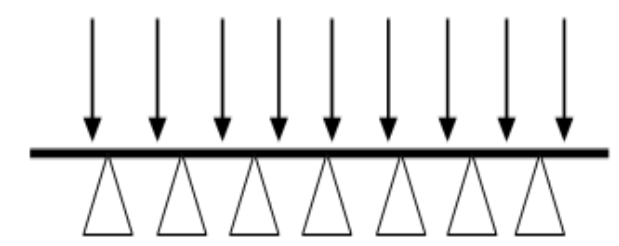

Gambar 4. Pola sebaran gaya pada Piezoelektrik

Sesuai yang digambarkan diatas, terlihat 7 piezo yang digunakan sebagai tumpuan untuk menahan gaya yang disebabkan oleh hujan sebagai sumber gaya.

Sesuai dengan perhitungan gaya aksi reaksi dapat digambarkan seperti Gambar 5.

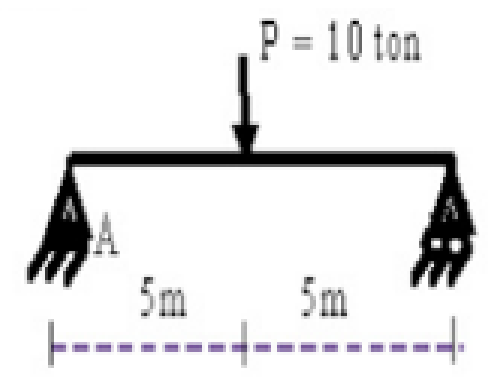

Gambar 5. Simulasi gaya aksi reaksi pada tumpuan

Berdasarkan hukum aksi reaksi gaya yang diterima pada bidang y akan bereaksi pada 2 tumpuan terdekat dari gaya yang diterima (nilai $\mathrm{p}=10$ ton dan $\mathrm{L}=5 \mathrm{~m}$, diasumsikan). Artinya jika ada tumpuan tambahan pada bagian kanan dan kiri. Tumpuan tersebut tidak menerima momen dari gaya kerja. Jika disimulasikan maka gambar yang terjadi seperti pada Gambar 6 .

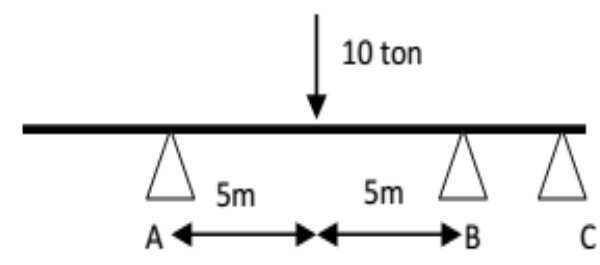

Gambar 6. Perhitungan simulasi gaya aksi reaksi

Perhitungan gaya dari Gambar diatas dengan menggunakan persamaan:

$$
\Sigma \mathrm{MA}=0
$$

Diperoleh hasil sebagai berikut:

$$
\begin{gathered}
-R B .10 m+P .5 m=0 \\
-R B .10 m+10 \text { ton. } 5 m=0 \\
-R B .10 m+50 \text { ton. } m=0 \\
-R B .10 m=-50 \text { ton. } m \\
R B=5 \text { ton }
\end{gathered}
$$

Dan,

$$
\Sigma \mathrm{MB}=0
$$

Diperoleh hasil sebagai berikut:

$$
\begin{gathered}
R A .10 m-P .5 m=0 \\
R A .10 m-10 \text { ton } .5 m=0 \\
R A .10 m-50 \text { ton. } m=0 \\
R A .10 m=50 \text { ton. } m \\
R A=5 \text { ton }
\end{gathered}
$$

Untuk kontrol digunakan persamaan:

$$
R A+R B=P
$$

Diperoleh hasil:

5 ton +5 ton $=10$ ton

10 ton $=10$ ton 
$\Sigma \mathrm{MC}=0$, Karena gaya momen dari gaya hanya diterima oleh Tumpuan a dan $b$.

Oleh karena itu dalam penelitian ini akan membentuk desain piezoelektrik dengan rincian gaya pada sumbu $\mathrm{x}$ dan $\mathrm{y}$ sebagai berikut seperti pada Gambar 7.

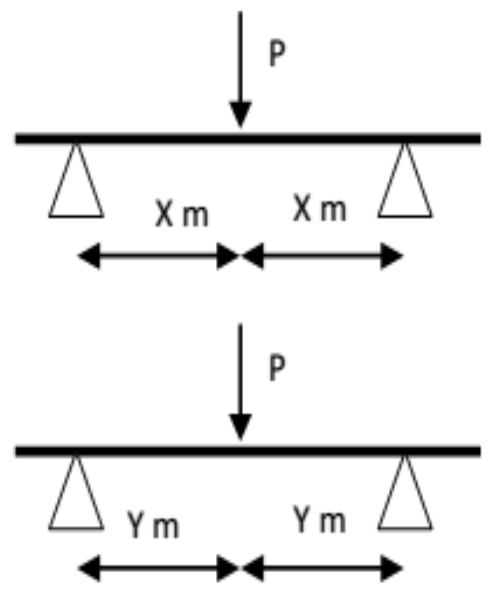

Gambar 7. Pola sebaran aksi dan reaksi pada Piezoelektrik

Dimana posisi X dan Y, seperti pada Gambar 8.

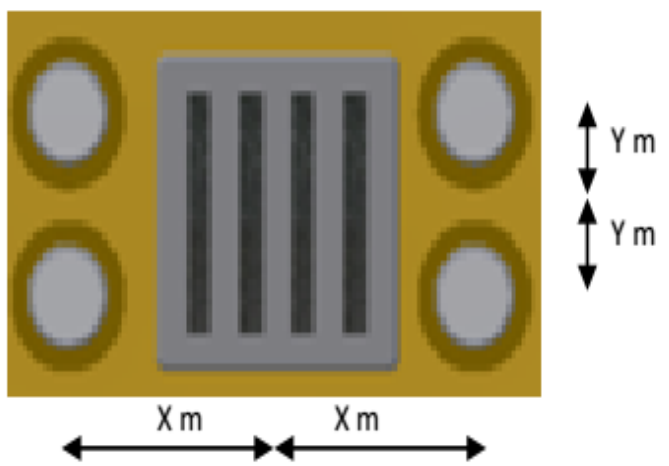

Gambar 8. Desain sistem pickup piezo electrik

Dimana dapat diartikan base punching akan diberikan permasing-masing 4 piezo untuk menerima gaya resultan yang lebih baik. Selain dari pembagian gaya momen yang kurang efektif. Pada penelitian sebelumnya pembuatan piezo dibuat melalui cetakan-cetakan yang membuat dimensi piezo memiliki dimensi yang tidak presisi. Sehingga menyebabkan perbedaan tinggi piezo. Seperti Gambar 9 berikut ini.

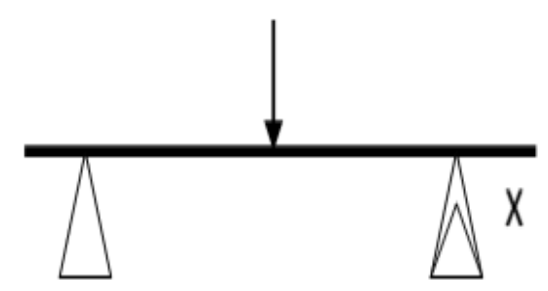

Gambar 9. Simulasi perbedaan tinggi

Pada Gambar 9. Titik X memperlihatkan bahwa perbedaan tinggi akan menyebabkan salah satu pilar piezo tidak akan menerima gaya resultan karena gaya diterima oleh komponen piezo yang berada pada bagian yang lain, sehingga resultan gaya tidak merata. Untuk mengatasi hal tersebut pada desain selanjutnya dilakukan dengan memberikan penyalur gaya dengan jarak tinggi yang bisa diatur. Sehingga perbedaan tinggi pada piezo bisa diatasi, seperti Gambar 10 dibawah ini.

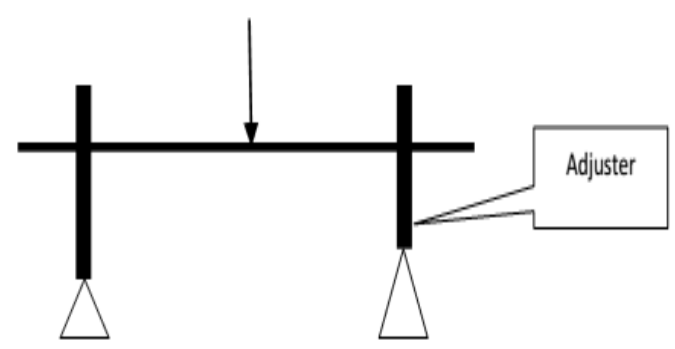

Gambar 10. Desain adjuster untuk punching piezo

Dengan adanya adjuster perbedaan tinggi pada piezo akan dapat teratasi dan pembagian resultan gaya momen akan tetap stabil. Sehingga dapat disimpulkan desain untuk piezoelectric akan membentuk 4 titik piezo sebagai tumpuan untuk mengatasi perbedaan gaya resultan yang terjadi. Dan juga diberikan adjuster untuk mengatasi perbedaan tinggi pada piezo.

\section{KESIMPULAN}

Dari hasil analisis desain pickup piezoelectrik dapat disimpulkan yaitu: perhitungan gaya aksi dan reaksi pada posisi piezolektrik perlu dilakukan untuk mengetahui pola sebaran hujan ke piezoelektrik membran, sehingga dapat ditentukan jumlah piezoelektrik yang 
akan digunakan dalam model Hybrid. Hasil perhitungan analisis sebara gaya diperlukan tambahan adjuster sebagai pembuat kondisi stabil pada susunan piezoelektrik.

\section{UCAPAN TERIMA KASIH}

Penulis menghaturkan ucapan terima kasih kepada Kementerian Riset, Teknologi dan Pendidikan Tinggi Republik Indonesia dan Kopertis Wilayah III serta Lembaga Penelitian dan Pengabdian Masyarakat (LPPM) Universitas Muhammadiyah Jakarta, yang telah mendukung dan mendanai penelitian ini melalui Hibah Penelitian Produk Terapan pada Tahun 2017.

\section{DAFTAR PUSTAKA}

Almanda, D., Dermawan, E., Ramadhan, A.I., Diniardi, E., Fajar, A. N., 2015, Analisis Desain Optimum Model Piezoelektrik PVDF Untuk Sumber Pembangkit Listrik Air Hujan Berskala Mini, Prosiding Seminar Nasional Sains dan Teknologi (Semnastek) 2015, Universitas Muhammadiyah Jakarta

Almanda, D., Dermawan, E., Diniardi, E., Syawaluddin, Ramadhan, A.I., 2016, Pengujian Desain Model Piezoelektrik PVDF Berdasarkan Variasi Tekanan, Prosiding Seminar Nasional Sains dan Teknologi (Semnastek) 2016, Universitas Muhammadiyah Jakarta

Almanda, D., Dermawan, E., Diniardi, E., Ramadhan, A.I., Hidayat, S., 2016, Design And Test Equipment Model Rain Water Based Energy Effect of Size of Printed Material of Piezoelectric In Indonesia, International Journal of Engineering Inventions, Vol. 5 No 7, pp. 48-55

Christianto, Paulus, et al. 2011. Piezo Vibration Sensor. Universitas Kristen Maranatha. Bandung

Febrawi, T., and Daryanto, B. W., 2013. Vibration Energy Harvesting In Washing Machines with piezoelectric mechanism, Journal of Engineering of POMITS, Vol. 2 No 1 , pp. 1-5
Hananto, F. S., et al. 2011. Application of Piezoelectric Material Film PVDF (Polyvinylide Flouride) As Liquid Viscosity Sensor, Journal of Neutrino, Vol. 3 No 2, pp. 129-142

Krisdianto, A. N., 2011. Characteristics Study of Energy Produced Vibration Mechanism Piezoelectric Energy Harvesting Methods To Imposition Frontal And Lateral, Institut Teknologi Sepuluh Nopember. Surabaya

Rahayu, S., et al. 2013. Piezoelectric Materials Synthesis BNT-BT With the addition of Ta2O5 Method Using Solid State Reaction. Universitas Andalas. Padang.

Ramadhan, A. I, Diniardi, E., Mukti, S.H., 2016, Analisis Desain Sistem Pembangkit Listrik Tenaga Surya Kapasitas 50 WP, Jurnal Teknik, Vol. 37 No 2, pp. 59-63, DOI: 10.14710/teknik.v37i2.9011

Sharma. 2006. Studies on Structural Dielectric and Piezoelectric Properties of Doped PCT Ceramics. Deemed University. Punjab

Ubaidillah, Suyitno, dan Juwana, Wibawa Endra, 2012, Pengembangan Piranti Hibrid Termoelektrik - Sel Surya Sebagai Pembangkit Listrik Rumah Tangga, Jurnal Litbang Provinsi Jawa Tengah, Vol.10 No.2, pp. 194-211

Widodo, Djoko Adi, Suryono, Tatyantoro A, 2010, Pemberdayaan Energi Matahari Sebagai Energi Listrik Lampu Pengatur Lalu Lintas, Jurnal Teknik Elektro Vol. 2 No.2, pp. 133-138 